\title{
CAN INTEGRATED LIVESTOCK-FISH CULTURE BE A SOLUTION TO EAST AFRICA'S FOOD INSECURITY? A REVIEW
}

Ogello EO* ${ }^{1}$, Mlingi $\mathrm{FT}^{2}$, Nyonje $\mathrm{BM}^{3}$, Charo-Karisa $\mathrm{H}^{4}$ and $\mathrm{JM}_{\text {Munguti }}{ }^{5}$

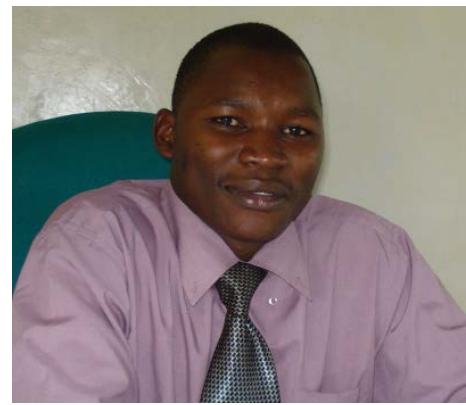

Erick Ochieng Ogello

*Corresponding author email: erioch2006@yahoo.com

${ }^{1 *}$ Kenya Marine \& Fisheries Research Institute, Kegati Aquaculture Research Station P.O Box 3259 - 40200, Kisii, Kenya

${ }^{2}$ Sokoine University of Agriculture, Department of Animal Science and Production

P. O. Box 3004, Morogoro, Tanzania

${ }^{3}$ Kenya Marine \& Fisheries Research Institute, Mombasa Station, P.O Box 81651 080100, Mombasa, Kenya

${ }^{3}$ National Aquaculture Research Development \& Training Centre (NARDTC), P.O. Box 26 - 10230, Sagana, Kenya

${ }^{5}$ Kenya Marine \& Fisheries Research Institute, P.O Box 451 - 10230 Sagana, Kenya. 


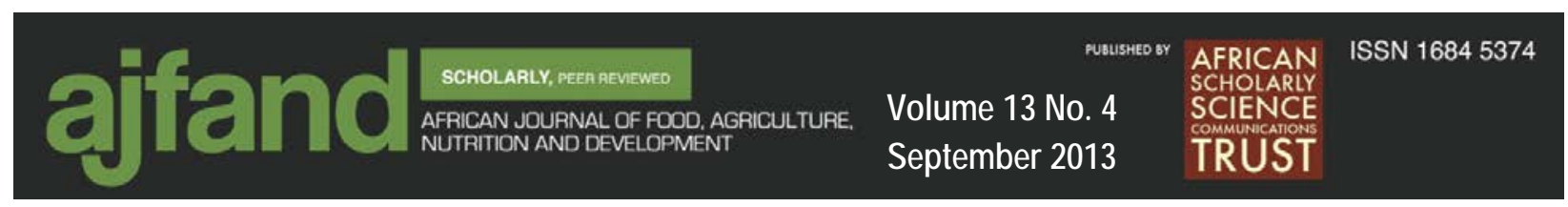

\begin{abstract}
Integrated livestock-fish culture approach envisages the integration of fish farming with cattle, sheep, goats, poultry, pigs or rabbit husbandry in a design allowing wastes from one system to be used as inputs in another system. The aim is to conserve resources while increasing farm returns. This paper reviews integrated livestock-fish culture in Asia and some African countries towards stimulating growth in East Africa's livestock-fish integration practices. Livelihood challenges and current status of integrated livestock-fish culture in some segments of East Africa are discussed. Economic analyses of integrated livestock-fish farming in selected places are presented. Challenges facing integrated livestock-fish aquaculture in the region include: government neglect of aquaculture sector, weak aquaculture research and applications, political interferences as well as social and religious challenges. Poor publicity, poor infrastructure, lack of clear legislations and policies and high illiteracy among potential fish farmers have also been mentioned as bottlenecks to the growth of integrated fish farming in the region. So far, fish-poultry integration is the most popular across Africa and Asia while fish-cattle integration is unpopular in many countries. Livestock manure as source of organic fertilizer for fish ponds and biogas production can help reduce cost of investment in purchasing inorganic fertilizers. With the present high cost of pelleted fish feeds, integrated fish farming stands to reduce the cost of feeding fish while simultaneously increasing the yield, leading to high economic returns. This paper concludes that livestock-fish integration is one of the most practicable solutions to food insecurity and malnutrition in the East African community despite its current poor status. In fact, it could be the forgotten asset that can guarantee present and future aquaculture sustainability in the region. The paper recommends capacity building among stakeholders to recognise integrated aquaculture as a 'self feeding' biotechnology unit, which deserves special attention in East Africa.
\end{abstract}

Key words: livestock-fish culture, integration, East Africa 


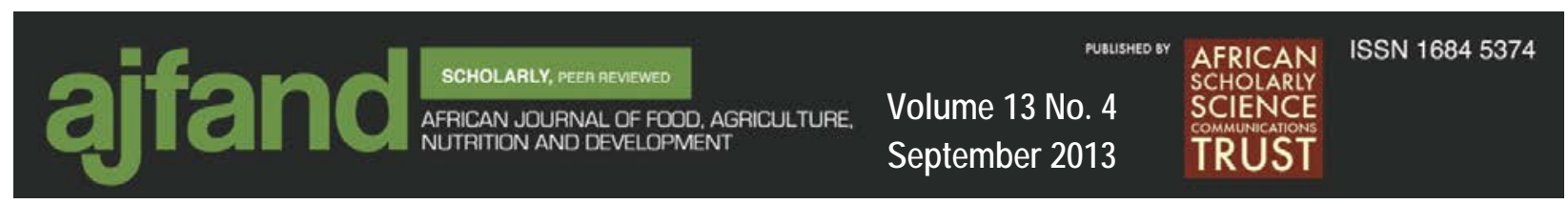

\section{INTRODUCTION}

Aquaculture is the controlled land-based or open-ocean farming of aquatic organisms such as fish, shellfish and even plants. Aquaculture contributes to human food fish demands, poverty alleviation and rural development and is often mooted as the fastest growing food production sector in the world [1]. Integrated Agriculture Aquaculture (IAA) combines aquaculture with different agricultural systems into an interactive relationship with the expectation that together, they will generate synergistic effects on conservation of resources and profitability [2, 3]. Livestock production and processing generate by-products that may be important inputs for aquaculture. The main linkages between livestock and fish production involve the direct use of livestock wastes, which function as fertilizers to stimulate natural food webs in fish ponds. The concept of Integrated Agriculture Aquaculture System (IAAS) was first conceived and explored in Asia in the late 1970s due to limited wild fish stocks; limited land space and high human population to fulfil food requirements $[4,5,6]$. Since then, some of these systems have been successfully applied in other developing countries and impressive yields have been reported [7]. Today, aquaculture production stands at 50:50 to capture fisheries on a global scale thanks to the technological advancements such as hybridization, genetic engineering, formulated diets and the integrated agriculture aquaculture [8]. However, the rate of aquaculture production is not uniform the world over [9]. In Asia, which is the epicentre of aquaculture production, aquaculture is integrated with agriculture providing millions of livelihood opportunities [10]. However, Africa is yet to report any significant quantities of integrated aquaculture products despite the natural potential [11].

In Africa, integrated aquaculture is mainly for subsistence purposes often carried out in the family backyards and publications even in national documents are very scanty [12]. Nevertheless, successful application of livestock-fish farming in Asia is a testimony that indeed it is positively correlated to enhanced productivity, food security, profitability and environmental sustainability [13]. Therefore, there is need to perform research studies on specific aquaculture-agriculture combinations that can yield best results in Africa.

In East Africa, aquaculture is generally under-developed, contributing less than $1 \%$ of total global fish production [14]. Similarly, integrated livestock-fish culture is still at a rudimentary stage and few successful impacts are documented [15]. Integrated livestock-fish culture could be one of the potential solutions to the continuous food insecurity, malnutrition and poverty for the small-scale and marginal farmers in the region [15]. The common denominator among the three major countries in East Africa (Kenya, Uganda and Tanzania) is the perennial food shortages and malnutrition [15]. There is need to embrace livestock-fish culture integration systems to cushion the farmers from persistent poverty and hunger. The functional advantage of integrated aquaculture is conservation, reutilization of resources and low space requirements. For instance, the amount of organic matter which can be recycled in ponds as fertilizers is up to $5 \mathrm{~g} \mathrm{C} \mathrm{m}^{-2} \mathrm{~d}^{-1}$, corresponding to $100 \mathrm{~kg}$ of dry manure $\mathrm{ha}^{-1} \mathrm{~d}^{-1}$ [16].

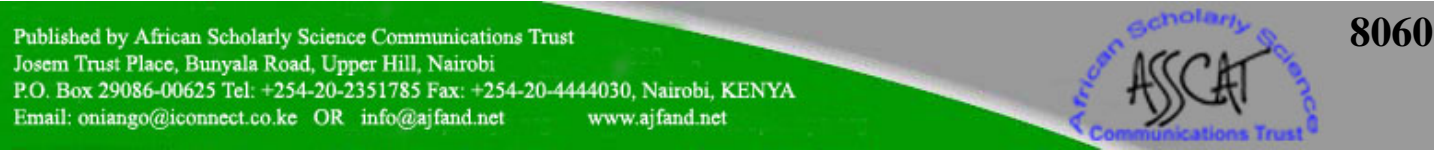


Out of this, the expected production in a polyculture unit (common carp and silver carp) may reach $30 \mathrm{~kg} \mathrm{ha}^{-1} \mathrm{~d}^{-1}$ without feeding the fish [16]. Such a yield is much higher than classical animal production on land [17]. Despite increased application of integrated livestock-fish farming worldwide, some shortcomings such as the transfer of diseases, high initial cost and special management skills needs have been reported [18].

Schematic flows of energy from one sector to the next in an integrated system are shown in Figure 1.

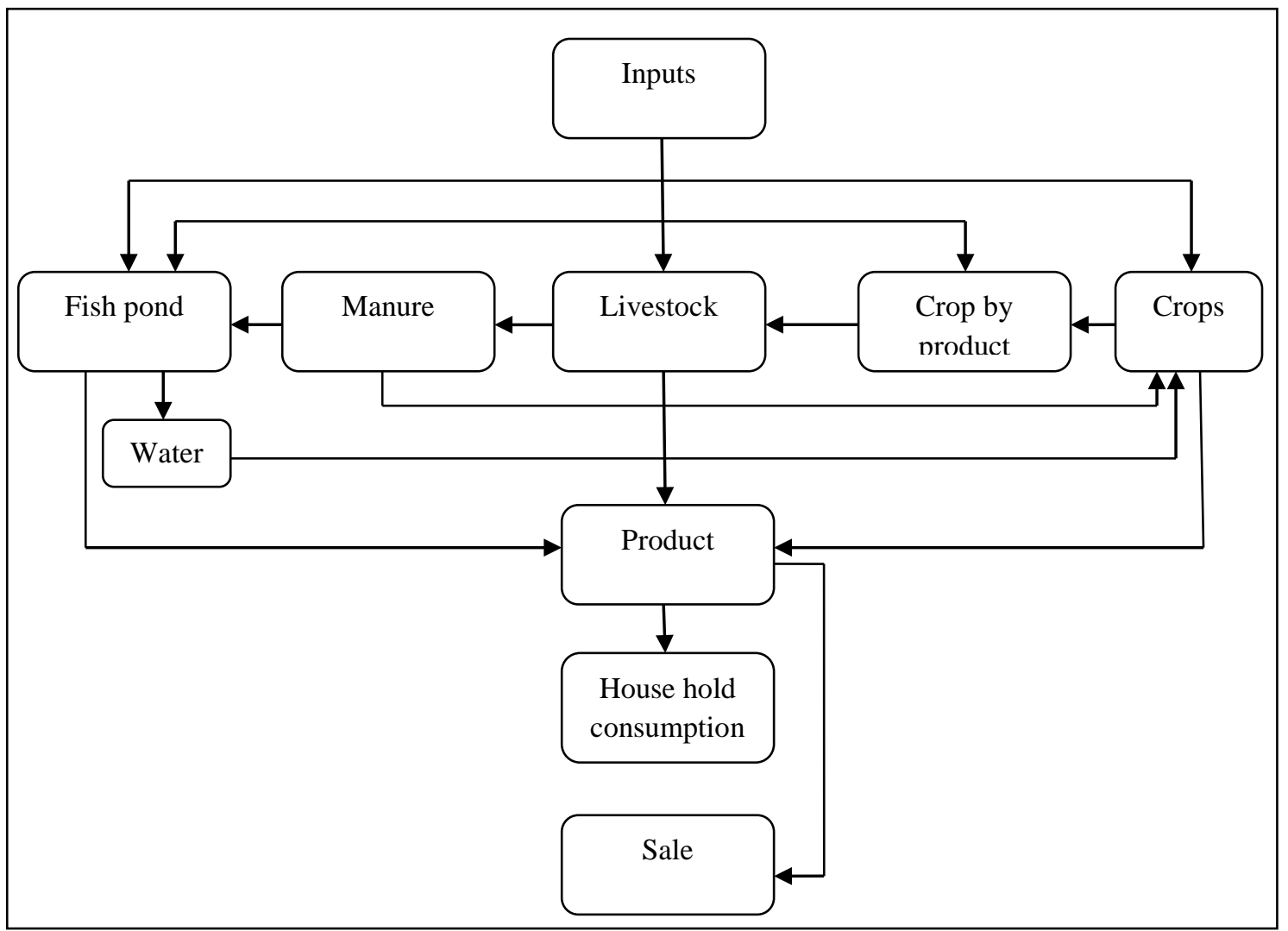

Figure 1: Schematic interactions between various subsystems in an integrated small scale agriculture-aquaculture system

Considering the economic and ecological contributions of integrated livestock-fish farming in other countries' rural economy, this paper critically appraises the potential of integrated livestock-fish farming (pig/fish, poultry/fish and cattle/fish) as a means of enhancing livelihood of every segment of the East African population. This paper discusses successful experiences in integrated livestock-fish culture in Asia and other African nations to encourage aquaculture stakeholders in the East African community to embrace integrated livestock-fish farming. It is hoped that the conclusions and recommendations presented here will be thought-provoking for a wide audience particularly policy makers, planners, NGOs, researchers and extension staff. It is 


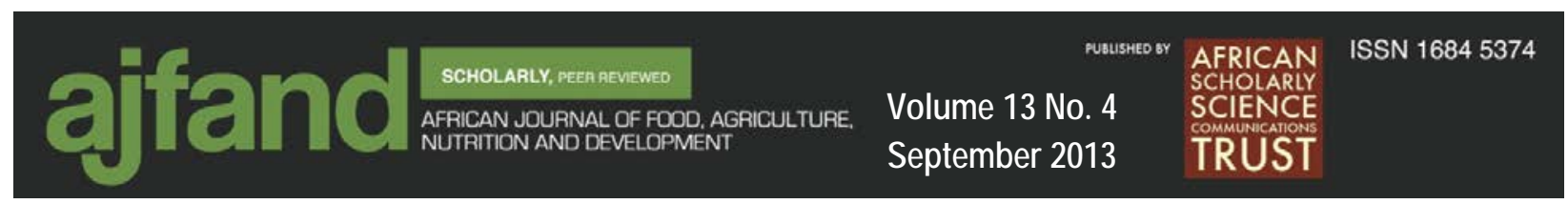

further hoped that the paper will stimulate actions to ensure that aquaculture development provides for reasonable rural livelihoods, a clean environment, and adequate food products.

\section{Livelihood challenges in East Africa}

Small scale farmers in developing countries are often poorer than the rest of the population, often getting less food to lead healthy lives [19]. Arresting poverty and hunger, therefore means confronting the problems that farmers face in their daily struggle for survival. East Africa with an estimated population of about 130 million is a fascinating region renowned for diversified natural resources including lakes, rivers, rainfall and good climate [19]. However, the majority of East Africans are still faced with threats of hunger and malnutrition [20]. East Africa's large rural populations depend mainly on rain-fed agriculture. Climatic hazards especially droughts have decreased production of staple crops, thus increasing pressure on water resources [21]. Human population pressure has caused land fragmentation therefore adoption of sustainable farming systems such as livestock-fish integrated culture is recommended [22]. Human poverty is the main obstacle to achieving economic and nutritional success in East Africa, while hunger and malnutrition remain amongst the most devastating problems facing developing countries [23]. Suggestions aimed at developing aquaculture in the East African region have emphasized intensive highinput systems rather than enhancing sustainable and improved traditional fish production techniques [24]. There is still a dearth of information on how to design integrated aquaculture systems, which are ecologically and economically sustainable in East Africa. Some major challenges of livestock-fish culture in the region include: lack of a comprehensive policy on aquaculture, poor information dissemination and technology transfer, low government funding, low investment by the private sector and incoherent promotion of aquaculture through many institutions including government, universities, research institutes, non-governmental organizations (NGOs) and other national authorities [25]. Inadequate effort has been put to strengthen the socio-economic sector of fisheries and aquaculture in the East African region [26]. Poor government priorities, illiteracy, limited publicity, strict cultural and religious doctrines are other bottlenecks facing livestock-fish culture in East Africa [26]. The communities bordering Lake Victoria have been reluctant to embrace fish farming activities despite declining fisheries stocks in the lake [26].

\section{Status of integrated livestock-fish culture in East Africa}

\section{Uganda}

Aquaculture sub-sector in Uganda has been described as a low-input, low-output undertaking [27]. However, aquaculture sector has grown over the last 5 years and many farmers are getting engaged through earthen ponds, cages and tanks [28]. Today, about 25,000 fish ponds covering 10,000 hectares producing 100,000 tonnes of whole fish annually has been reported [28]. However, the current status of integrated fish farming in Uganda is still at infancy stage and is largely undocumented [28]. Few farmers have demonstrated the potential of integrated

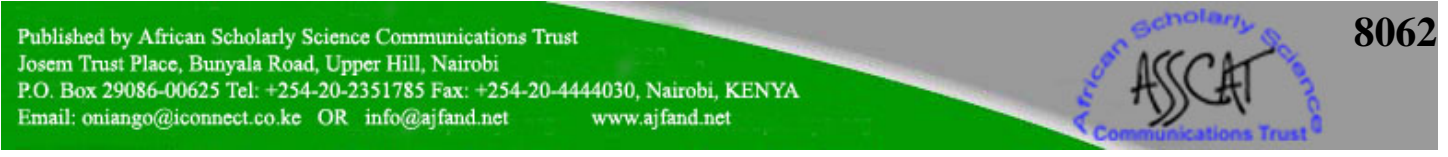


livestock-fish farming in parts of Uganda. For instance, polyculture of the African catfish (Clarias gariepinus) and the Nile Tilapia (Oreochromis niloticus) integrated with poultry and/or other livestock is common in Senya, Central Uganda where unpublished reports showed productivity of up to 3.7 tons $^{-1} \mathrm{y}^{-1} \mathrm{year}^{-1}$ of C. gariepinus and O. niloticus (whole fish) [28, 29]. Despite enormous resources and great potential, the integrated livestock-fish farming has failed to take off due to social and economic challenges [30]. Integrated livestock-fish aquaculture is confined to remote villages by few poor farmers with little knowledge, whose work in most cases is unreported even in national aquaculture statistics [30]. In this regard, the authors recommend a special focus on the farmers through on-farm research and demonstrations, identifying and training farmers with leadership potential through formation of farmers' associations.

\section{Kenya}

In Kenya, livestock-fish culture is demonstrated by the state owned institutions like the Lake Basin Development Authority (LBDA) in Kisumu and the Kenya Marine and Fisheries Research Institute (KMFRI) in Sagana. A large number of farmers have embraced the practice across the country where they use mainly chicken and cow dung manure for pond fertilization [31]. However, there are no documented farming procedures and outputs of integrated-livestock fish culture in Kenya despite enormous potential. In Kisii, Kenya, integrated rabbit-fish farming has been initiated by few farmers [31]. However, there is no documented information showing the productivity potential and a lot of technical information is still lacking.

In 2009, the Kenyan Government funded a national fish farming program as part of efforts to promote fish farming, create employment and contribute towards reducing food insecurity in the country [32]. Unfortunately, no funds were allocated for the integrated livestock-fish farming despite its enormous potential. To date, some fish farmers have registered impressive performance in some parts of the country [32]. Furthermore, a few farmers have established integrated fish- poultry systems and have reported marginal returns despite the fact that the level of integration is still rudimentary [32]. Studies on integrated livestock-fish culture on the Kenyan side of the Lake Victoria Basin reported that a $200 \mathrm{~m}^{2}$ fish pond of $O$. niloticus manured with cow dung provided an additional per capita fish supply of $3.4 \mathrm{~kg}$ to a household of 7 people and an average productivity of about $200 \mathrm{~kg} \mathrm{ha}^{-1}$ year ${ }^{-1}$ [33]. Fertilization of nurseries and rearing ponds with cow dung is a widespread practice in Kenya and fresh cow dung from two cows is sufficient to fertilize 1 ha of pond area [33]. Such initiatives should be encouraged by the Ministry of Fisheries and research institutions. All stakeholders should promote integration of fish farming with other traditional cropping and livestock production systems. Need-based research should be prioritised.

\section{Tanzania}

Fish farming in most part of Tanzania is practiced as standalone activity, which can be a risky venture, because of economic factors such as the price instability [34]. Aquaculture in Tanzania began in the late 1950s with the pond culture of tilapia

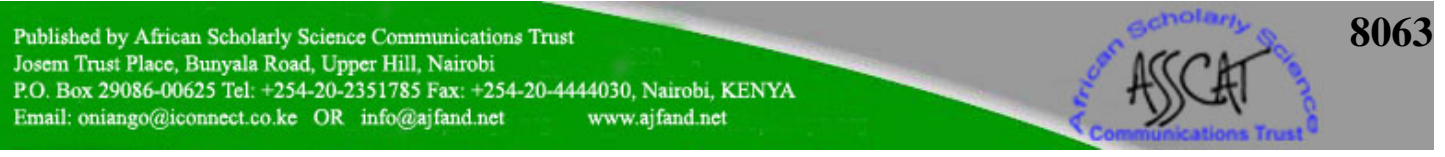




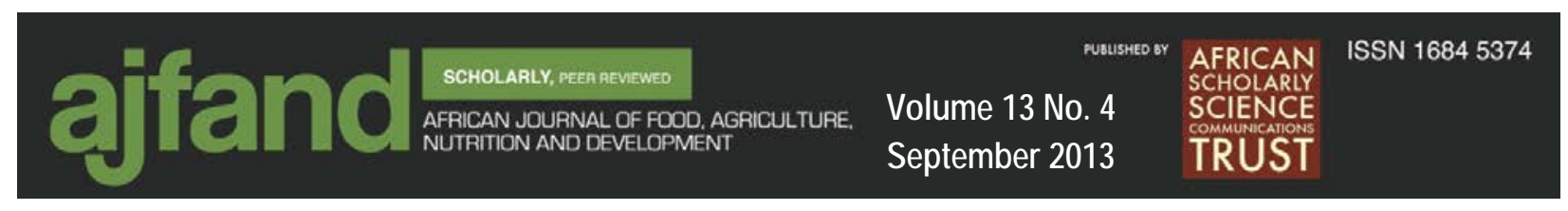

species native to the region [35]. To date, it has not done any better. In the early 1970s, international donor funded projects were responsible for establishing an estimated 8,000 - 10,000 ponds producing about 2,000 tons of fish per year [35]. The number of fish ponds fell to less than 1,000 by 1985 due to poor management, inappropriate technologies, inadequate extension efforts, poor marketing and infrastructure [35, 36]. Despite a decline in pond tilapia production in Tanzania, livestock-fish culture is still viewed as a possible source of livelihood for farmers in the coastal region that is closer to the urban markets of Dar es Salaam [36]. The sector of integrated fish culture is largely neglected [37].

A comparison of growth performance of integrated fish pond (fertilized with manure and fed with vegetables) and non-integrated culture of tilapia was conducted in Tanzania. Results from the study showed that fish cultured under the integrated system exhibited higher growth rates than those in non-integrated systems (Figure 2). The observations were similar to other findings that integrated fish farming increases yield and produces fish based on the same land, water and labour [38]. Recently, a study conducted in Morogoro, Tanzania reported the use of livestock manures to fertilize Nile tilapia ponds by small scale farmers [39]. The farmers, however, realized low production due to unscheduled fertilization and improper feeding [39]. These systems should prove more attractive to the small scale fish farmers who are the majority in East Africa.

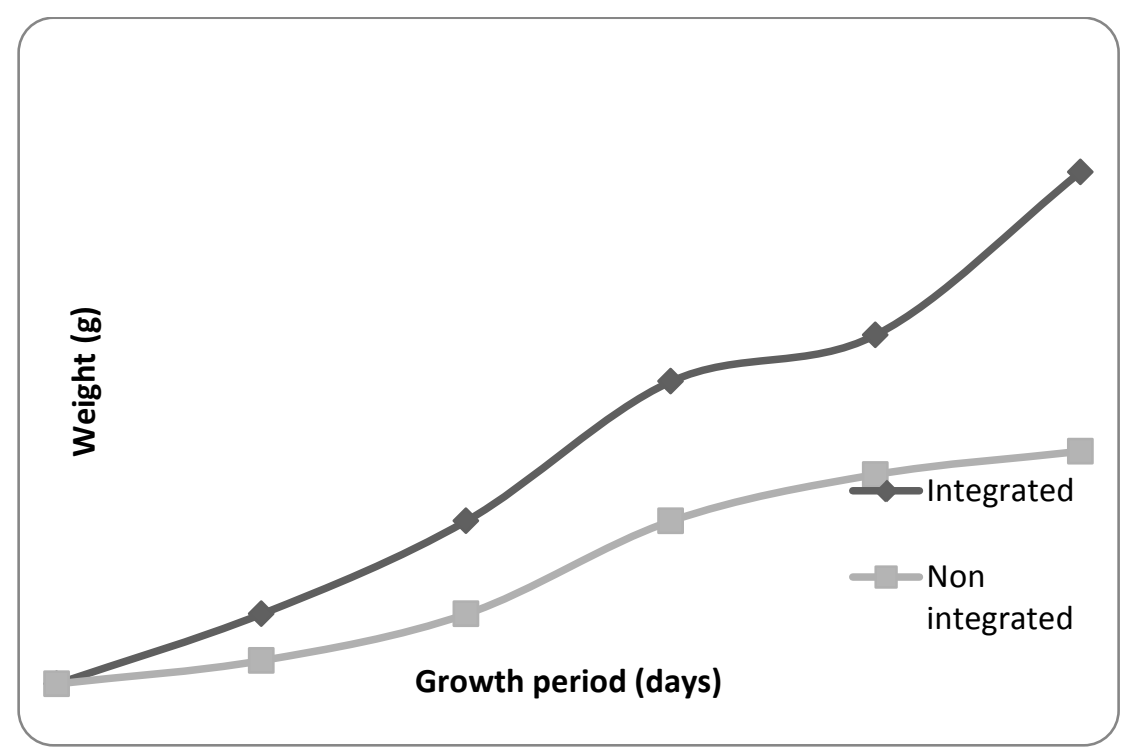

Figure 2: Growth trends of Nile tilapia reared under integrated and non-integrated systems in Tanzania [34] 


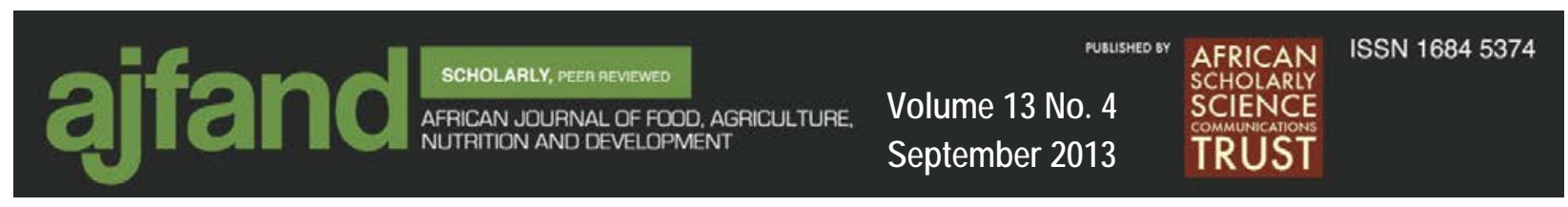

\section{Detailed analyses of integrated livestock-fish farming}

\section{Pig cum fish integrated culture}

The pig is a highly prolific animal that easily feeds on cheap kitchen wastes and aquatic plants [40]. The excreta, which are nitrogen-rich, are used as organic manure in fish ponds [41]. In well managed pig-fish farming operations, whole fish production of $2-5$ tons ha ${ }^{-1}$ in 6 months and $4-5$ tons ha $^{-1}$ in 6 months of pork was reported in Nigeria [41]. In addition, farmers practicing pig-fish farming have reported 28\% - 30\% economic advantage over normal pig farming [41, 42]. A successful case is integrated pig-fish-duck of Kafue Fisheries Company in Zambia with a total pond area of 37 ha producing 1.5 tons week $^{-1}$ of $180-250 \mathrm{~g}$ fish mostly indigenous tilapias (Oreochromis andersonni, Oreochromis mossambicus, $O$. niloticus, C. gariepinus and Cyprinus carpio) [43]. The main market for the fish is Lusaka (Zambian capital) at 3,000 Zambian Kwacha per kg, equivalent to US \$ 0.81 [43]. Monoculture of Tilapia andersonii with pigs yielded 7 tons of whole fish ha ${ }^{-1}$ year $^{-1}$ in Zambia while monoculture of C. gariepinus with pigs yielded 7.5 tons of whole fish $\mathrm{ha}^{-1} \mathrm{year}^{-1}$ in the Central Africa Republic with the growth rate of $2.9 \mathrm{~g} \mathrm{day}^{-}$ ${ }^{1}$ for C. gariepinus [44]. Even though excreta of three pigs may just be sufficient to fertilize a pond of $1,000 \mathrm{~m}^{2}$ in one production cycle, more than $30 \mathrm{pigs} \mathrm{ha}^{-1}$ pond is recommended [45] to ensure sufficient supply of biofloc community for pond microbial synthesis and periphyton development [46]. Biofloc and periphyton also serve as additional food for fish [47]. Most of these promising examples of integrating fish with livestock are in countries within sub-Saharan Africa with similar climatic conditions to East Africa and, therefore, the same results can be achieved or even surpassed in East Africa if priority is given.

\section{Poultry cum fish integrated farming}

Birds reared for eggs (layers) or meat (broilers) can be integrated with fish farming to reduce the cost of inputs such as fertilizer and feed to maximize profits [48]. The poultry house can be raised over the pond (vertical integration) to minimise transport and maximizing land usage. The excreta from the birds serve as manure, which fertilizes the pond or the fish can feed on them directly [48]. Nutrient content of fish reared in chicken manure fed ponds is better than fish fed with pellet feeds [49]. Poultry manure is sufficient to raise tilapia from hatching to maturity [50]. A tilapia selection breeding program recorded highest growth response for tilapia under chicken manure alone compared to artificially fed tilapia [50].

In the Philippines, O. niloticus, common carp and snakeheads polyculture with broilers (stocked at 5,000 ha-1), gave an estimated productivity of 7.3 tons of whole fish ha ${ }^{-1}$ year $^{-1}$ [51]. In the Central African Republic, egg laying chicken (at a stocking density of 3,000 ha ${ }^{-1}$ ) integrated with $O$. niloticus (30,000 fingerlings ha ${ }^{-1}$ ), during a grow-out period of 189 days in $500 \mathrm{~m}^{2}$ ponds, produced 5.5 tons of fish ha ${ }^{-1}$ year $^{-1}$, plus 2,746 eggs year ${ }^{-1}$ [52]. In another case, ponds stocked with O. nilotius (20,000 fingerlings ha ${ }^{-1}$ ) and C. gariepinus (100 fingerlings ha ${ }^{-1}$ ), combined with 1,500 Peking ducks ha ${ }^{-1}$ produced $3.8-4.5$ tons of fish ha $^{-1}$ year $^{-1}$ and up to 6 tons ha ${ }^{-1}$ year ${ }^{-1}$ (live 


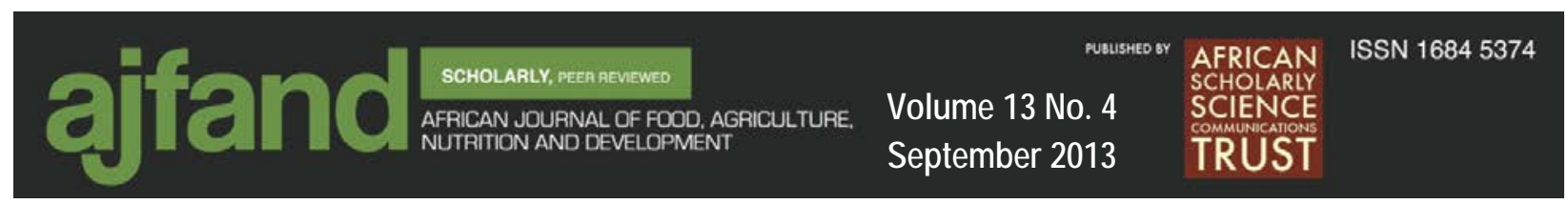

weight) of ducks [52]. In India, culture of common carps at a stocking density of 6,340 fingerlings $\mathrm{ha}^{-1}$ integrated with ducks $\left(100 \mathrm{ha}^{-1}\right)$ yielded 4.3 tons of fish ha ${ }^{-1}$ year $^{-1}, 250 \mathrm{~kg}$ of ducks (live weight) and 1,835 eggs [53]. All these are promising results. However, the East African region needs to define relevant aspects applicable to the region.

As presently practised, the combination of duck and fish farming is considered as a means of reducing the cost of feed for ducks and an inexpensive way of fertilizing fish ponds. In this integrated system, ponds provide living and foraging areas for the ducks and fish. Hence, the rationale for integrated duck-fish culture is stronger than many other animal-fish systems [53]. However, ducks being 'manuring machines', they can cause eutrophication problems in the ponds [53] and feed on fish fingerlings leading to losses. It is important to provide adequate supplementary feeds to the ducks. Studies should be initiated to determine optimal number of animals to provide sufficient manure per unit pond area for optimal fish production. This will prevent farmers from either over or under-fertilizing their fish ponds. Table 1 below indicates the recommended number of animals and quantities of manure in integrated livestockfish culture in Thailand [54]. There is need for the East African region to develop a locally fitting schedule.

\section{Cattle cum fish integrated farming}

Cattle are kept for beef and milk and for other benefits like hides and skins, labour for land preparation, transport and manure production. Fish farming can become more productive if it is integrated with cattle farming. Cattle graze on pond banks and grassy areas in the vicinity and manure is either collected or washed directly from the cattle sheds into the ponds [55]. This method helps to check land availability problems and reduces labour cost. Culture of Chinese carps in a pond manured with $15,000 \mathrm{~kg} \mathrm{ha}^{-1}$ year $^{-1}$ of cow dung, produced 5 tons ha ${ }^{-1}$ year ${ }^{-1}$ of whole fish [55]. However, cattle-fish integrated farming is not popular perhaps due to the high cost of rearing cattle [56]. East Africa is blessed with large herds of cattle. With the domestic markets for fish expanding, capture fisheries cannot meet the demand for fish therefore the widening supply and demand gap for fish. This offers growing opportunities for aquaculture production and this can be achieved faster through integrated fish farming $[57,58,59]$.

\section{Economic analysis of integrated fish farming}

The economic benefit of integrated fish farming cannot be over-emphasized. It contributes immensely to the economic empowerment of many families especially in rural communities. It enables the farmer to be productive all the year round and fully maximize production as risks are evenly spread [59]. An analysis of economic returns from both integrated and non integrated tilapia farm in Tanzania revealed that an integrated farm gave higher economic returns compared to a non-integrated one (Table 2).

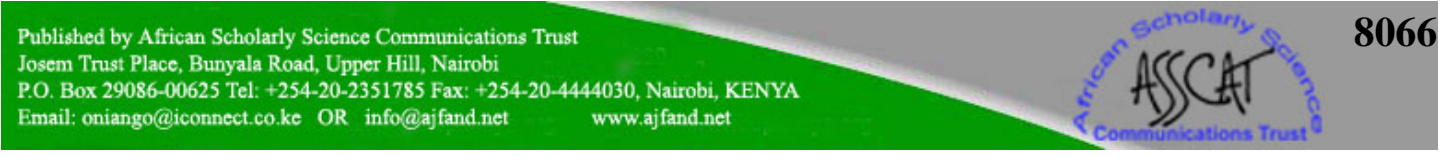




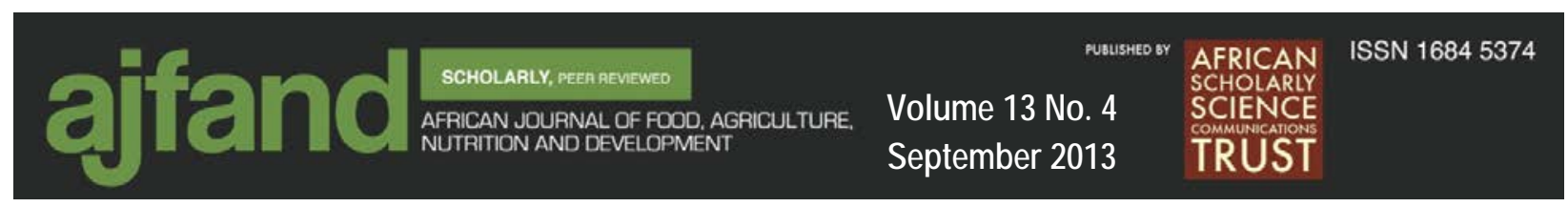

In the Philippines, a pig-fish farm sized 0.1 ha yielded a profit equivalent to Ksh 27,024 in six months (Table 3). Also, a fish-chicken farm sized 0.1 ha recorded profit equivalent to Ksh 20,245 in Bangladesh after six months (Table 4).

\section{Conclusion and recommendations}

Integrated livestock-fish farming approach as a biophysical and socio economic capsule has an immense potential to address income instability, nutritional insecurity, unemployment, and poverty of farmers in the larger East African community. Indeed integrated fish farming is inexpensive and profitable and could be the forgotten asset for present and future sustainable aquaculture development. The urgency in addressing issues of livelihood security, empowering rural poor through enhanced fish production process in an integrated manner in East Africa needs no further emphasis. Production yields from integrated fish farming vary depending on the livestock and the management system preferred. However, all cases of integrated fish culture have proved to be more profitable than unitary system of farming as it ensures the spread of financial risk. As an ecologically friendly activity characterised by reduced wastes, the ecological importance must be taken into consideration as this leads to aquaculture sustainability. In this regard, clear linkages between aquaculture and the environment must be defined and made known to all stakeholders. Studies are needed to optimize the production of the different integration components through closing nutrient circles in order to maximise benefits. Aquaculture promotion in the region should be more inclined to crop and animal husbandry than to fisheries, where it currently belongs. Similarly, specific policies tailored to integrated farming instead of unpractical, highly intensive aquaculture systems are recommended. 
Table 1: Doses of manure required for maximum production in livestock-fish integrated systems in Thailand [54]

\begin{tabular}{llll}
\hline Animals & Animals/ha of fish pond & Fresh manure (Kg/adult/day) & Maximum manure (Kg/ha/day) \\
\hline Pigs & $30-3000$ & 5 for 100kg pig & 150 \\
Chicken & $1000-4000$ & 0.15 for $1.5 \mathrm{~kg}$ bird & $150-600$ \\
Ducks & $750-3000$ & 0.2 for $2 \mathrm{~kg}$ bird & $150-600$ \\
\hline
\end{tabular}

Table 2: Economic comparison between Tilapia fish harvested from integrated and non-integrated culture systems in ponds in Tanzania [34]

\begin{tabular}{lll}
\hline Parameter & $\begin{array}{l}\text { Integrated } \\
\text { (USD) }\end{array}$ & $\begin{array}{l}\text { Non-integrated } \\
\text { (USD) }\end{array}$ \\
\hline Gross revenue & 20,770 & 2,694 \\
Variable cost & 12,775 & 3,389 \\
Income above variable cost & 7,995 & 0 \\
Fixed cost & 2,780 & 2,780 \\
Total cost & 14,773 & 6,170 \\
Net return & 5,996 & 0 \\
Break-even yields (above variable cost) & $8,296.46$ & $2,200.84$ \\
Break-even yields (above total cost) & $9,593.38$ & $1,805.81$ \\
(kg/ha) & & \\
Break-even price (above variable cost & 4.55 & 3.73 \\
Break-even price (above total cost) & 5.26 & 3.06 \\
\hline
\end{tabular}


Table 3: Budget for fish-pig farming in 0.1 ha pond in Philippines. The costs have been converted to Kenya shillings [60]

\begin{tabular}{ll}
\hline Particulars & Cost in Kshs. \\
\hline Fish culture & \\
Pond preparation with 15kg bleaching powder and 15kg urea at 8.56/kg & 258 \\
Fingerlings (850 at 250/1000) & 439 \\
Liming (25 kg at 2/kg) & 103 \\
Nets and labour for harvesting & 824 \\
Fish culture equipment & 52 \\
Pond rental & $\underline{619}$ \\
& $\underline{2,295}$ \\
Pig raising & \\
Pigsties & 2,062 \\
Fattening of two lots of piglets for six months each & 186 \\
First lot weaned piglets & 2,227 \\
Pig feed (540 kg at 2/kg) & 2,413 \\
Second lot & $\underline{82}$ \\
Medicine & $\underline{4,866}$ \\
& 7,161 \\
Total cost & 1,074 \\
Interest on the working capital @15\% & 8,236 \\
Total operational cost & \\
Income & 24,744 \\
Fish sale (600 kg at 20/kg) & 10,516 \\
Meat sale (300 kg live weight at 17/kg) & 35,260 \\
Balance/profit & 27,024 \\
\hline
\end{tabular}


Table 4: Shows economic analysis of fish-chicken integrated farming/ha in Bangladesh. The costs have been converted to Kenya shillings [60]

\begin{tabular}{|c|c|c|c|}
\hline Species & Number & $\%$ & $\begin{array}{l}\text { Cost } \\
\text { (Ksh) }\end{array}$ \\
\hline Silver carp & 400 & 40 & 80 \\
\hline Catla & 100 & 10 & 100 \\
\hline Grass carp & 50 & 5 & 50 \\
\hline Rui & 150 & 15 & 30 \\
\hline Common carp & 100 & 10 & 50 \\
\hline Sarputi & 100 & 10 & 50 \\
\hline Mrigal & 100 & 10 & 20 \\
\hline Total fingerling & 1000 & & 380 \\
\hline Running cost & & & 500 \\
\hline Lime & & & 200 \\
\hline Fertilizer: Cow dung & & & 200 \\
\hline Urea & & & 30 \\
\hline TSP & & & 20 \\
\hline Netting charges & & & 500 \\
\hline Pond rental cost & & & 2,000 \\
\hline Fish total & & & 3,830 \\
\hline \multicolumn{4}{|l|}{ Chicken section } \\
\hline Chicken cost (105 birds) & & & 10,500 \\
\hline Annual depreciation of chicken house & & & 1,600 \\
\hline Feed ( Ksh 8.5 /kg) & & & 37,230 \\
\hline Labour & & & 3,210 \\
\hline Chicken total & & & 53,540 \\
\hline Contingencies & & & 1000 \\
\hline Interest on working capital (12\%) & & & 6,885 \\
\hline Total Operating cost & & & 64,255 \\
\hline \multicolumn{4}{|l|}{ Sales } \\
\hline Sale of fish $(550 \mathrm{~kg} \times \mathrm{Ksh} 35)$ & & & 19,250 \\
\hline Sale of eggs ( $65 \%$ laying rate) $\left(23,700 \times 2.5^{*} \mathrm{Ksh}\right)$ & & & 59,250 \\
\hline Sale of 100 hen & & & 6,000 \\
\hline Total sale income & & & 84,500 \\
\hline Net profit & & & 20,245 \\
\hline Return on total operating cost (\%) & & & $31.5 \%$ \\
\hline
\end{tabular}




\section{REFERENCES}

1. FAO. The State of World Fisheries and Aquaculture. FAO Fisheries and Aquaculture Department, Food and Agriculture Organization of the United Nations Rome, 2010.

2. Ayinla OA Integrated fish farming: A veritable tool for poverty alleviation/Hunger eradication in the Niger Delta Region. In A.A Eyo and J.O Atanda (eds). Conference Proceedings of Fisheries Society of Nigeria, Owerri, Nigeria. 2003; 40-41.

3. Chen FY Chicken Farming in integrated fish farming Regional Aquaculture, Center Wuxi China. NACA Technical Manual, 1989; 11: 4-30.

4. Edwards P, Kaewpaitoon K, McCoy EW and C Chantachaeng Pilot small scale crop livestock-fish integrated farm. AIT. Research Report, 184 AIT, Bangkok, Thailand, 1986; 131 pp.

5. Rajbanshi KG and MB Shrestha A case study on the economics of integrated farming systems: Agriculture, aquaculture and animal husbandry in Nepal. In: Integrated Agriculture Aquaculture Farming Systems, R.S.V. Pullin and Z.H. Shehadeh (eds), ICLARM Conf. Proc. 4, 1980; 195-208.

6. Vincke MMJ Integrated Farming of Fish and Livestock: Present Status and Future Development 1992. FAO. Rome 1992.

7. FAO. Aquaculture extension in sub-Saharan Africa. Fisheries Circular No. 1002. Food and Agriculture Organization of the United Nations, Rome, 2004b; 55 pp.

8. FAO. Fisheries global information system. FAO Fisheries and Aquaculture Department, Food and Agriculture Organization of the United Nations Rome, 2012.

9. Bostock J, McAndrew B, Richards R, Jauncey K, Telfer T, Lorenzen K, Little D, Ross L, Handisyde N, Gatward I and R Corner Aquaculture: global status and trends. Philosophical Transactions Royal Society Biological sciences, 2010; 365: 2897-2912.

10. Edwards P and D Little Integrated livestock-fish farming system. Food and Agriculture Organization of the United Nations Rome, 2003.

11. FAO. The State of World Fisheries and Aquaculture. FAO Fisheries and Aquaculture Department, Food and Agriculture Organization of the United Nations Rome, 2008. 
12. Jamu D Tilapia culture in Africa: Opportunities and challenges. In S. Subasinghe and S Tarlochan (eds.). Tilapia: production, marketing and technological developments. Proceedings of the Tilapia International Technical and Trade Conference on Tilapia, Kuala Lumpur, Malaysia. 2001; 105-112.

13. Prein $\mathbf{M}$, Lightfoot $\mathbf{C}$ and RSV Pullin ICLARM's approach to the integration of aquaculture into sustainable farming system. In: ADB/NACA Report on a Regional Study and Workshop on Aquaculture Sustainability and Environment. Network of Aquaculture Centres in Asia, Bangkok Thailand and the Asian Development Bank, Manila, 1998; 257-265 pp.

14. FAO. Small ponds make a big difference. Integrating fish with crop and livestock farming. Farm Management and Production Economics Service Inland Water Resources and Aquaculture Service. FAO, Rome, 2000.

15. Rasowo J, Auma E, Ssanyu G and M Ndunguru Does African catfish (Clarias gariepinus) affect rice in integrated rice-fish culture in Lake Victoria Basin, Kenya? African Journal of Environmental Science and Technology, 2008; 2 (10): 336-341.

16. Billard RN, De Pauw JC, Micha $\mathbf{C}$ and $\mathbf{J}$ Verreth The impact of aquaculture in rural management. In: Aquaculture Society. 1990 Special Publ. No. 12, N. De Pauw and R. Billard (Eds) Bredene, Belgium.

17. Birley $\mathbf{M}$ and $\mathbf{K}$ Lock Health and peri-urban natural resource production. Environment and Urbanization, 1998; 10 (1): 89-106.

18. Buras N Bacteriological Guidelines for Sewage-Fed Fish Culture. In: P. Edwards \& R.S.V. Pullin, eds. Wastewater-Fed Aquaculture, Proceedings of the International Seminar on Wastewater Reclamation and Reuse, Bangkok, Environmental Sanitation Information Center. Asian Institute of Technology. 1990; 223-236.

19. EAC. Food safety, a critical matter for the region. $4^{\text {th }}$ East African Commission development strategy (2012-2016), Deepening and accelerating integration 2012.

20. FAO. State of World Fisheries and Aquaculture (SOFIA). Food and Agriculture Organization of the United Nations, Fisheries Department, Rome, 2004a 153 pp.

21. WFC Fish an issue for everyone: A concept paper for fish for all Summit. World Fish Centre 2003; 10p. 
22. Korikantimath VS and BL Manjunath Integrated farming systems for suatainability in agricultural production. Proceedings of national symposium on new paradigms in agronomic research. Indian Society of agronomy. Navsari Agriculture University. Gujarat, 2008; 279 - 281pp.

23. Qureshi AW Animal production: an African perspective. WAAP Newsletter, 1996; No. 35: 25- 31. August.

24. Kipkemboi J, Van Dam AA and $\mathbf{P}$ Denny Biophysical Suitability of Smallholder Integrated Aquaculture-Agriculture Systems (Fingerponds) in East Africa's Lake Victoria Freshwater Wetlands International Journal of Ecology and Environmental Sciences 2006; 32 (1): 75-83.

25. Mwangi MH A Comparative Economic Evaluation of Farming of Three Important Aquaculture Species in Kenya, UNU- Fisheries Training Programme 2007.

26. Wetengere $\mathbf{K}$ Socio-economic factors critical for adoption of fish farming technology: The case of selected villages in Eastern Tanzania. International Journal of Fisheries and Aquaculture, 2009; Vol. 1 (3): 028-037.

27. MAAIF Development of a Fisheries Sector Strategic Plan (FSSP) 2003-2012. Aquaculture and Culture Based Fisheries Components. Ministry of Agriculture Animal Industry \& Fisheries, Uganda 2003.

28. MAAIF Development of a Fisheries Sector Strategic, Plan Ministry Of Agriculture Animal Industry \& Fisheries, Department Of Fisheries Resources Annual Report 2010/2011.

29. Maseruka J Lack of Funds Affects Fish Farmers' Progress in Uganda. Published by The New Vision, 21st July 2004.

30. Aganyira K Aquaculture: A Tool for Sustainable Development in Uganda. A Case study of Kigoowa Catholic Women's Development Association in Kampala District. Master's thesis in Development Studies, Faculty of Social Science and Technology Management Norwegian University of Science and Technology Spring 2005, Trondheim-Norway.

31. Ogello EO and MA Opiyo A review of the African catfish production in Kenya: Opportunities and challenges. Aquaculture development in Kenya towards food security, poverty alleviation and wealth creation. Samaki news: 2011; Vol. VII. No. 1.

32. Nyonje M, Charo-Karisa $\mathbf{H}$, Macharia SK and M Mbugua A review of the African catfish production in Kenya: Opportunities and challenges. Aquaculture development in Kenya towards food security, poverty alleviation and wealth creation, Samaki news: 2011; Vol. VII. No. 1.

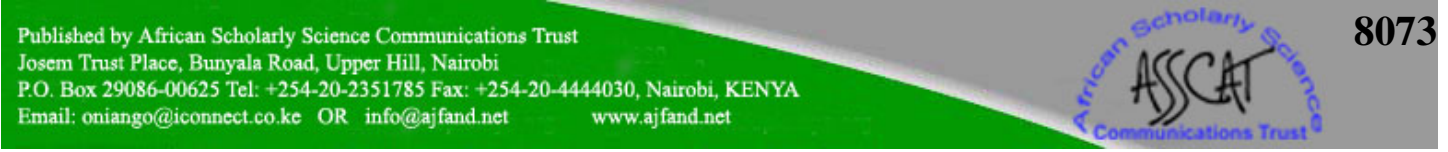


33. Van Dam AA, Kaggwa RC and J Kipkemboi Integrated pond aquaculture in Lake Victoria wetlands. In M. Halwart \& A.A. van Dam, eds. Integrated irrigation and aquaculture in West Africa: concepts, practices and potential, FAO. 2006; 181 pp.

34. Shoko AP, Getabu A, Mwayuli G and YD Mgaya Growth Performance, Yields and Economic Benefits of Nile Tilapia Oreochromis niloticus and Kales Brassica oleracea cultured Under Vegetable-Fish Culture Integration. Tanzanian Journal of Science, 2011; 37: 37-48.

35. Balarin JD National reviews for aquaculture development in Africa: FAO Fish Circular. 1985; (770.7): 96.

36. MLFD Ministry of Livestock and Fisheries Development, Fisheries Sector Development Programme 2010 United Republic of Tanzania.

37. Rice MA, Mmochi AJ, Zuberi $\mathbf{L}$ and RM Savoie Aquaculture in Tanzania. World Aquaculture 2006, pp 50-57.

38. Edwards P Integrated fish farming. Infofish Internantional. 1991; 5:45.

39. Chenyambuga SW, Madalla NA and BV Mnembuka Management and value chain of Nile tilapia cultured in ponds of small-scale farmers in Morogoro region, Tanzania. 2012, Unpublished data.

40. Ansa EJ and $\mathbf{J}$ Jiya Effect of pig Manure on the growth of O. niloticus under Integrated Fish-pig faming system. Journal of Aquaculture 2002; 17 (2): 8587.

41. AIFP. Farming Nigeria waters Newsletter of the Aquaculture and Inland Fisheries project of the National special Programme for food security in Nigeria. FAO Office Abuja, Nigeria. 2005; 3 (4): 2 - 4.

42. Pullin RSV Aquaculture, Integrated resources management and the environment. In: Mathias, J.A.; Anthony T. Charles; Hu Baotong (Eds.) Proceedings of a Workshop on Integrated Fish Farming held in Wuxi, Jiangsu Province, People's Republic of China. October 11-15, 1994. CRC Press. Boca Raton, New York, 1998; 19 - 42 p.

43. Lally E Zambian farm finds a winning formula. Fish Farmer 2000; 14-35.

44. Williams MJ Aquaculture and Sustainable Food Security in the Developing World. In: John E. Bardach (Ed.). Sustainable Aquaculture. John Wiley \& Sons, Inc., New York, 1997;15-51 pp. 
45. Jhingran VG and BK Sharma Integrated livestock fish farming in India. In Research plans for integrated aquaculture, Dhaka, Bangladesh, FAO/UNDP 1986; 46 -53pp.

46. Dhawen A and S Kaur Pig dung as pond manure effect on water quality, pond productivity and growth of crops in polyculture systems. ICLARM 2002; (25:11): 11-14.

47. Crab R, Defoirdt T, Peter Bossier $\mathbf{P}$ and W Verstraete Biofloc technology in aquaculture: Beneficial effects and future challenges Aquaculture 2012; 356-357 351 - 356.

48. Gabriel U, Akinrotimi OA, Bekibele DO, Anyanwu PE and DN Onunkwo Economic benefit and ecological efficiency of integrated fish farming in Nigeria. Scientific Research and Essay 2007; Vol. 2 (8), pp. 302 - 308.

49. Hu BT and HZ Yang Integrated management of fish-cum-duck farming and its economic efficiency and revenue. NACA/WP/84/14, 4 p. Bangkok, NACA, 1984.

50. Charo-Karisa H, Komen H, Rezk MA, Ponzoni RW, Van Arendonk JAM and $\mathbf{H}$ Bovenhuis Heritability estimates and response to selection for growth of Nile tilapia (Oreochromis niloticus) in low-input earthen ponds. Journal of Aquaculture 2006; 261: 479 - 486.

51. Edwards $\mathbf{P}$ The future potential of integrated farming systems in Asia. Proc. VWCAP 1983; 273 - 281.

52. Kapetsky JM A strategic assessment of warm-water fish farming potential in Africa. CIFA Technical Paper, No. 27. Rome, FAO, 1994; 67 pp.

53. Woynarovich E Raising ducks on fish ponds. In: R.S.V. Pullin and Z.H. Shehadeh (eds.). Integrated agriculture aquaculture farming systems. 1980, ICLARM Conf. 4, pp. 129 - 134.

54. STOAS. Integrated fish farming in the tropics Book 1 Aquaculture volunteered in Thailand foundation for the development of Agricultural Education and training Wageniga Netherland, 1993; 40 - 42.

55. Schroeder GL Fish farming in manure-loaded ponds, p. 73-86. In R.S.V. Pullin and Z.H. Shehadeh (eds.) Integrated agriculture-aquaculture. ICLARM 1980; Conference Proceedings 4, 258 p.

56. Ayoola SO sustainable fish production in Africa. African Journal of Food Agriculture Nutrition and Development 2010; Vol. 10 No. 5. 
57. Jayanthi $\mathbf{C}$ and $\mathbf{C}$ Vennila Integrated farming systems and sustainability for livelihood security. National symposium on new paradigms in agronomic research. 2008; 281 -283 Pp.

58. Jhingran AG Integrated fish-livestock-crop farming and its role in developing rural economy. Bull. Cent. Inland Fish. Res. Inst., Barrackpore, 1986; (48): 1.1- 4 .

59. Mathias $\mathbf{J}$ Integrated fish farming in the context of world food security. In: Mathias, J.A; Anthony T. Charles; Hu Baotong (Eds.) Proceedings of a Workshop on Integrated Fish Farming held in Wuxi, Jiangsu Province, People's Republic of China. October 11-15, 1994. CRC Press. Boca Raton, New York, 1998; 3 - 18 pp.

60. Arboleda CR Integrated livestock - fish production system in the Philippines; In: Mukherjec TK (eds). Proceedings FACT/IPT workshop on integrated livestock-fish production systems (Kuala, Lumpur, Institute of Advances studies University of Malaysia, Kuala Lumpur. 1992; 95 - 100. 